\title{
Scholars and Literati at the University of Fermo (1585-1800)
}

\author{
Giovanni Di Caprio Mara Vitale \\ IRES/LIDAM, UCLouvain
}

This note is a summary description of the set of scholars and literati who taught at the University of Fermo from 1585 to the eve of the Industrial Revolution (1800).

\section{The University}

The history of the University of Fermo has long been based on dubious or incomplete information. Many historiographers have erroneously corroborated the local tradition that it was founded in 1303 by Pope Benedict VIII. It is more likely that an authorization to open a university was given in the late 14th century. (See the Anecdotes section). However, although teaching is attested in the city of Fermo in the 15th and 16th centuries, it cannot be said that a true academic institution existed. It was only in 1585 , with a bull by Pope Sixtus V, that the opening (or reopening) of the university was granted (Brizzi 2001). In Fermo, the Jesuits also played a significant role. In 1609, an agreement was signed with the city and the then cardinal archbishop of Fermo, providing for their participation in teaching activities (Grendler 2019). In particular, they were given the chairs of theology, grammar, and philosophy. The university functioned until 1826 when it was closed because the city did not have sufficient resources to maintain it.

\section{SOURCES}

To construct the list of professors of the University of Fermo, we mainly used three books: "L'Università degli studi di Fermo: notizie storiche" by Vincenzo Curi (1880), "Bibliothèque de la Compagnie de Jésus" by Carlos Sommervogel (1890), and "Formazioni ed esercizio della professione medica a Roma e nella Marca Fermana nei secoli XVII - XVIII" by Fabiola Zurlini (2012). The first one is structured in chapters that follow the timeline and cover the history of university. The author also gives a list of all the professors who taught during that period. The second one was used to add information concerning the Jesuit professors at the University. The last one provided data on the doctors who taught at Fermo. To complete the biographical information, we used the dictionaries of Istituto dell'Enciclopedia Italiana (1929). Finally, Gian Paolo Brizzi's book "L'antica università di Fermo"(2001) proved a valuable source to reconstruct the university's history and allowed us to complete the list of professors.

\section{SOME STATISTICS}

Table 1 shows some descriptive statistics. There are a 561 scholars. With the official start of the academic activity in 1585, we observe an increase in the number of scholars. This is also explained by the greater economic resources available to the university in this early stage. We know the year of birth for $13.9 \%$ of the members. The mean age at nomination is 37.2 years. In the case of the University of Fermo, the longevity (average age at death and expected age at death when 30 ) is very high. The birth place is known for $81.1 \%$ of the people. The median distance between birth place and Fermo is $14 \mathrm{~km}$. Finally, $96.3 \%$ of the scholars have a Wikipedia page (in some language), which 
is a very high number, and $88.2 \%$ of them have left a footprint in the catalogues of the libraries of the world, Worldcat.

\begin{tabular}{|c|c|c|c|c|c|c|}
\hline \multicolumn{2}{|c|}{ Period } & \multirow{2}{*}{$\begin{array}{l}\text { nb. } \\
\text { obs }\end{array}$} & \multirow{2}{*}{$\begin{array}{l}\% \text { birth year } \\
\text { known }\end{array}$} & \multirow{2}{*}{$\begin{array}{l}\text { mean age } \\
\text { at appoint. }\end{array}$} & \multirow{2}{*}{$\begin{array}{l}\text { mean age } \\
\text { at death }\end{array}$} & \multirow{2}{*}{$\begin{array}{l}\text { life exp. } \\
\text { at } 30\end{array}$} \\
\hline Start & End & & & & & \\
\hline 1348 & 1449 & 11 & 0 & & & 30 \\
\hline 1450 & 1526 & 15 & 6.7 & & & 38 \\
\hline 1527 & 1617 & 91 & 11 & 47 & 64.2 & 55.6 \\
\hline 1618 & 1685 & 250 & 11.6 & 36.2 & 70.7 & 70.1 \\
\hline 1686 & 1733 & 23 & 34.8 & 32.5 & 69.4 & 72.5 \\
\hline 1734 & 1800 & 171 & 17.5 & 32.2 & 72.1 & 80.8 \\
\hline \multirow[t]{2}{*}{1200} & 1800 & 561 & 13.9 & 37.2 & $69 . \overline{7}$ & 69.2 \\
\hline & & & $\begin{array}{c}\% \text { birth place } \\
\text { known }\end{array}$ & $\begin{array}{l}\text { median distance } \\
\text { birth-institution }\end{array}$ & $\begin{array}{c}\% \text { with } \\
\text { Wikipedia }\end{array}$ & $\begin{array}{c}\% \text { with } \\
\text { Worldcat }\end{array}$ \\
\hline 1348 & 1449 & & 100 & 13 & 90.9 & 100 \\
\hline 1450 & 1526 & & 80 & 26 & 100 & 86.7 \\
\hline 1527 & 1617 & & 94.5 & 24 & 94.5 & 84.6 \\
\hline 1618 & 1685 & & 71.2 & 0 & 98.8 & 91.2 \\
\hline 1686 & 1733 & & 78.3 & 0 & 82.6 & 65.2 \\
\hline 1734 & 1800 & & 87.7 & 55 & 95.3 & 88.3 \\
\hline 1200 & 1800 & & $81 . \overline{1}$ & 14 & $\overline{9} \overline{6} . \overline{3}$ & 88.2 \\
\hline
\end{tabular}

Table 1: Summary statistics by period

\section{FIELDS}

Figure 1 shows the distribution of fields for all scholars. The University started as a school of law and rhetoric, so it is not surprising that the two main fields are: law and humanities. In addition, it also features theology, with the presence of Jesuits, and medicine, another important field at the University.

\section{Place OF BIRTH}

Figure 2 is a plot of the places of birth of the scholars. Northern Italy and Middle Italy are dominant. The presence of Jesuits and the good reputation of the faculty of medicine are the key explanation for the scholars who came from elsewhere.

\section{HUMAN CAPITAL OF SCHOLARS AND LITERATI}

For each person in the database, we compute a heuristic human capital index, identified by combining information from Worldcat and Wikipedia using principal component analysis. We also compute the notability of the university at each date by averaging the human capital of the scholars active at the University of Fermo 25 years before that date. The details are given in the Appendix. Figure 3 shows the names of all the scholars with a positive human capital index. The orange line plots the notability of the University. The vertical green lines (rug plot) show the distribution of all scholars, including the obscure ones, over time. Despite the presence of some professors with a high level of human capital, the notability of the university remains globally very low. This is because the most known professors were also professors at other universities, hence their publications were not credited in full to the University of Fermo. 


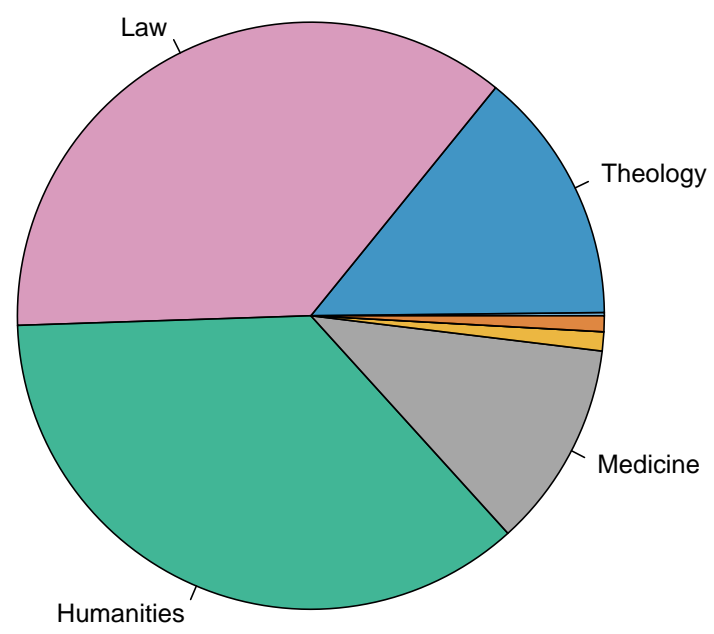

Figure 1: Broad fields at Fermo

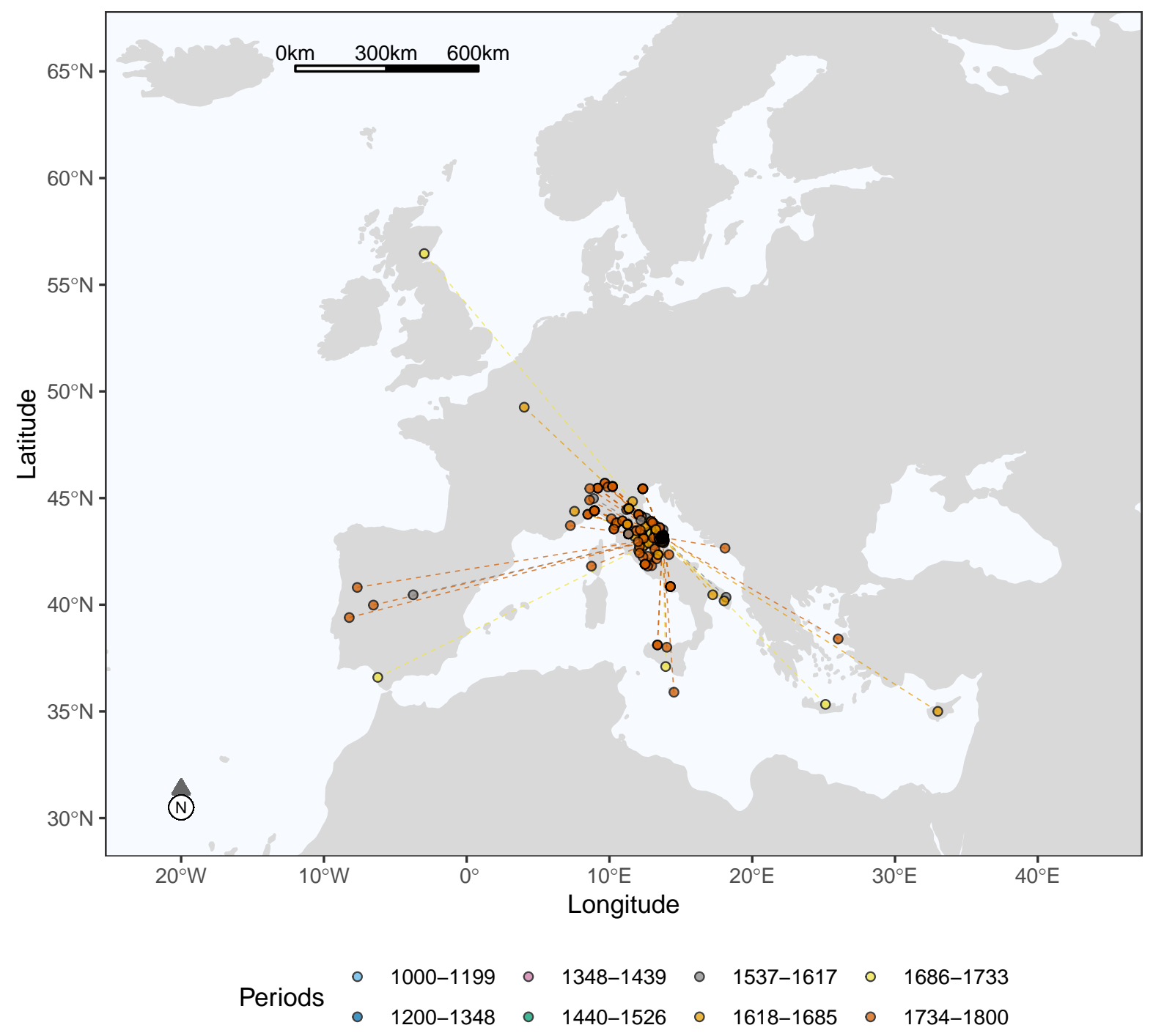

Figure 2: Places of birth of the scholars and literati at the University of Fermo 


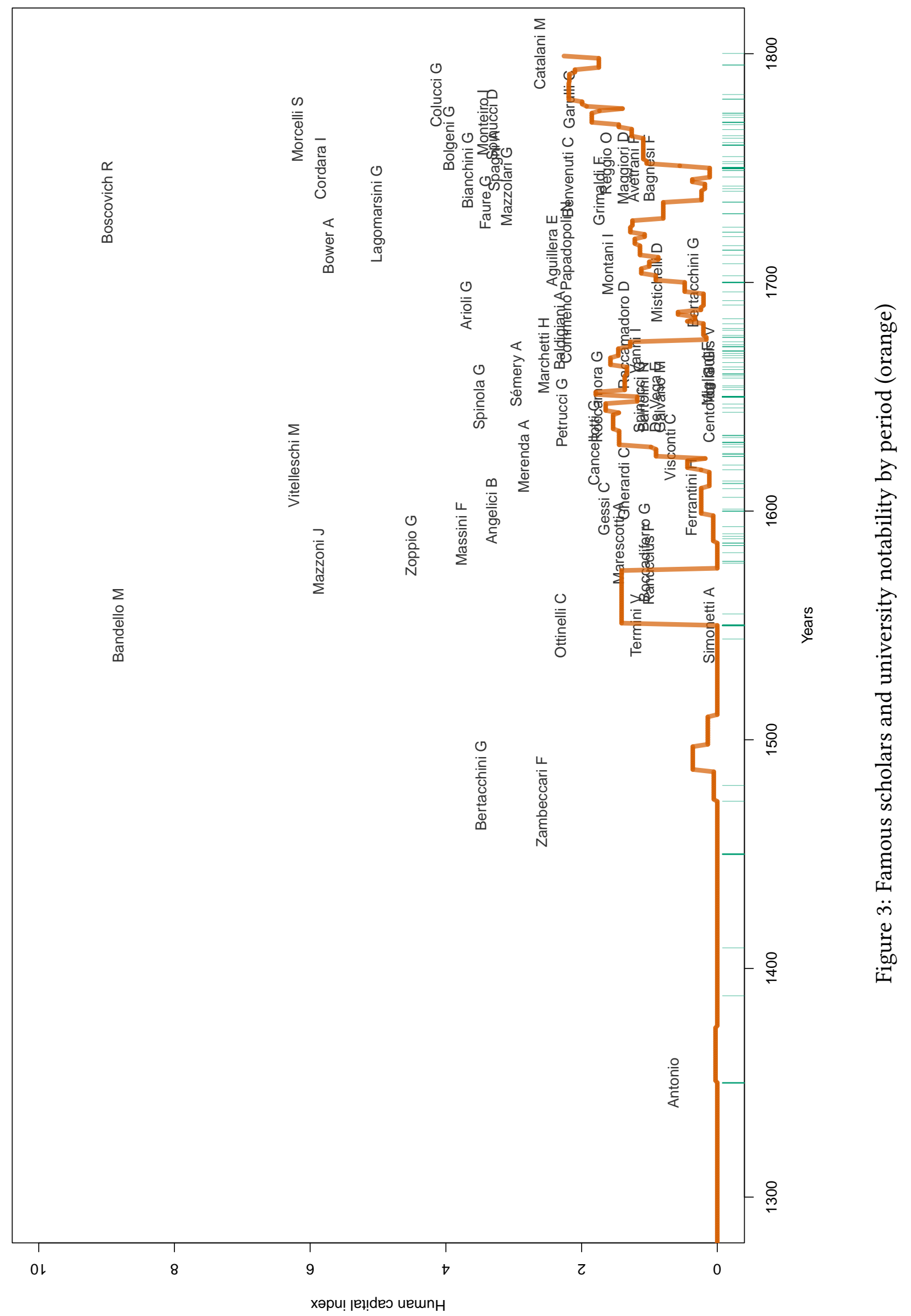




\section{TOP 5 PROFESSORS}

We now provide a brief overview of the five professors with the highest human capital index.

Ruggero Giuseppe Boscovich (Dubrovnik 1711 - Milano 1787), a member of the Jesuits, he was appointed professor of mathematics at the Gregorian University (De la Croix and Karioun 2021). He was a great physicist and astronomer. He worked on various fields of physics, contributing to the discovery of the absence of an atmosphere on the Moon and of the geometric process to determine the equator of a planet. In addition, he was a precursor of atomic theory. He was a member of several prestigious scientific academies. He moved to Fermo for health reasons, and taught philosophy there for two years.

Matteo Bandello (Castelnuovo Scrivia 1485 - Bazens 1561) was a Catholic bishop and writer. He is considered one of the most important novelists of the Renaissance. It is said that his novellas inspired Shakespeare for his plays such as Much Ado about Nothing and Romeo and Fuliet (Britannica, The Editors of Encyclopaedia 2021). According to Curi(1880), Bandello gave lectures at the University of Fermo.

Muzio Vitelleschi (Rome 1563 - Rome 1645) was a Jesuit and professor of philosophy and theology at the Gregorian University. He collaborated with Bellarmine in the drafting of his work Disputationes de Controversiis (1559-1574) and was elected Superior General (or Black Pope) of the Society of Jesus in 1615. He obtained the canonization of the founder of the order, Ignatius of Loyola. Curi counts him among the lecturers at the University of Fermo.

Stefano Antonio Morcelli (Chiari 1737 - Chiari 1821) was a Jesuit scholar and an epigraphist. His work "De stilo Latinarum inscriptionum libri III" is considered a milestone in epigraphy and gave him his European fame. He was a brilliant Greek scholar too and translated several Greek books into Latin. In Fermo, he taught at the College of the Jesuits from 1765 to 1767.

Giulio Cesare Cordara (Alessandria 1704 - Alessandria 1785) was born into a noble family. He became a Jesuit at the age of fourteen and taught at various colleges of the Order. He was a well-known historian and litterateur, not only for his knowledge but also for his proficiency in poetry and rhetoric. In 1737 , he published the satires De tota graeculorum huius aetatis litteratura, in which he defended the teaching method of the Jesuits, in open controversy with the pompous erudition of eighteenth-century intellectuals. Cordara's satires triggered a long and violent controversy, so much so that they were placed on the Index by Pope Clement XII. He was also a historian of the Order.

\section{RELATED SCHOLARS}

Jacopo Mazzoni (Cesena 1548 - Cesena 1598) was a philosopher, scholar, and astronomer. A member of several Academies (Crusca, Fiorentina, and Catenati), he was a professor of philosophy at Macerata, Pisa, and Rome. Curi counts him among the professors of law. The work In universam Platonis et Aristotelis philosophiam preludia (1597), in which Mazzoni supported the Aristotelian geocentric system, led to Galileo Galilei's response. This letter is the oldest evidence of Galileo's heliocentric theory.

\section{FAMILIES OF SCHOLARS}

We have identified three family groups with more than five people who were professors at the University of Fermo. Unfortunately, we have not been able to determine their degree of kinship, but we know that they belonged to the nobility of the city. The Paccaroni and the Raccamadori counted 10 professors at the University. 


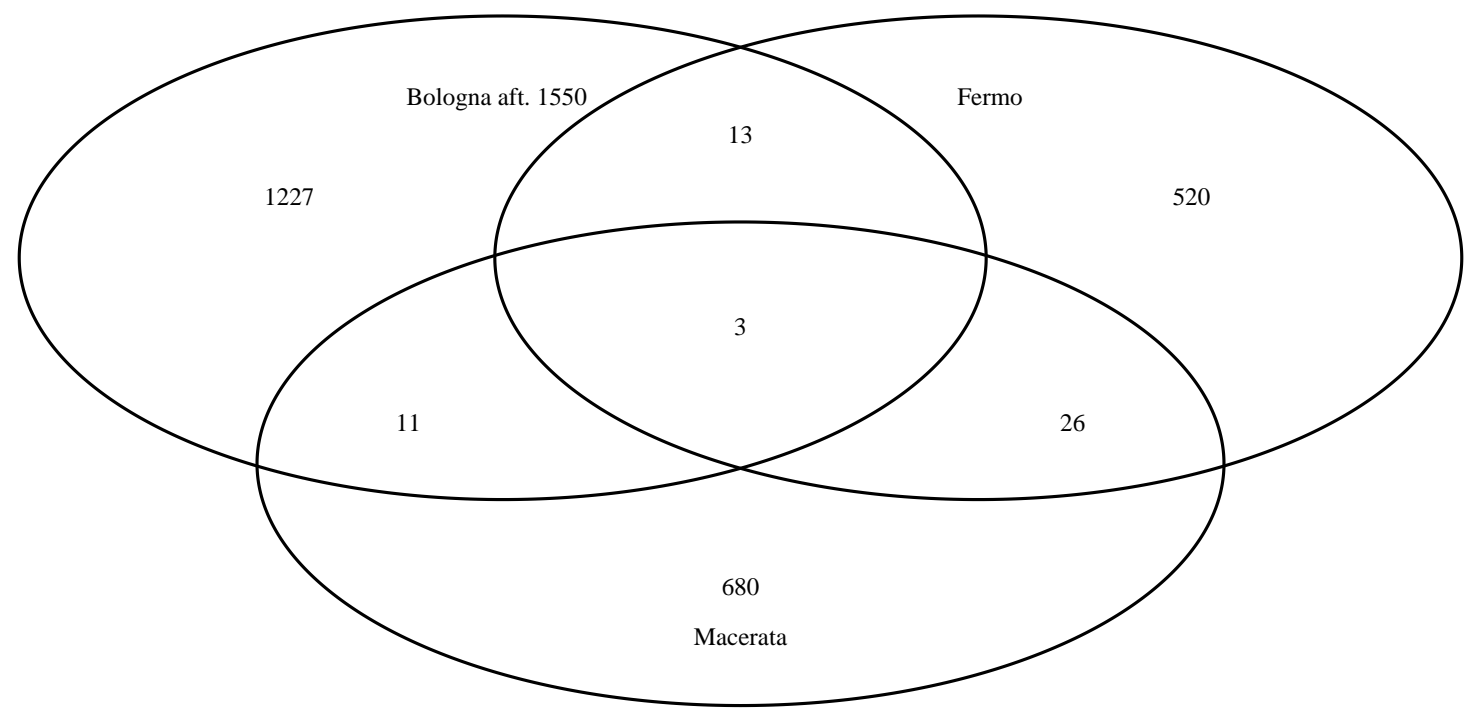

Figure 4: Intersection of the lists of scholars between the University of Fermo and the Universities of Bologna and Macerata

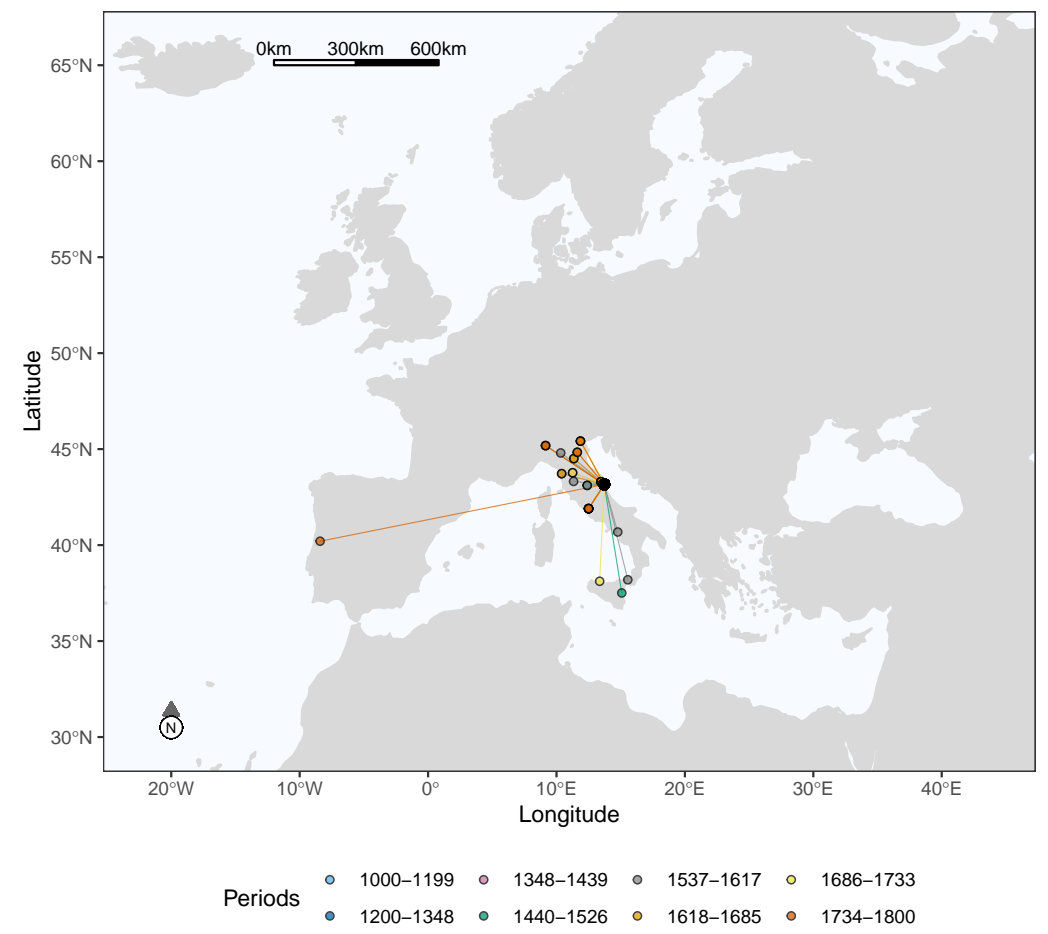

Figure 5: Links between the University of Fermo and other universities through scholars' mobility, by period 


\section{Intersection With the Universities of Bologna AND MaC- ERATA}

Figure 4 shows the intersection between the Universities of Fermo, Bologna, and Macerata. 13 professors taught at Bologna and Fermo, and 26 at Macerata and Fermo. The first case reflects the will of the University of Fermo to increase its prestige by calling on scholars from the University of Bologna. The second case, on the other hand, highlights how geographical proximity could facilitate the exchange of professors.

\section{UNIVERSITY NETWORK}

Here, we assume that when a professor occupied a position at more than one university over his/her life, this established a link between those universities. The universities with which Fermo is linked are displayed in Figure 5 As can be seen in the case of Fermo, the links are exclusively with Italian universities.

\section{AnecDotes}

For a long time, historiography indicated January 16, 1303 as the founding date of the University of Fermo, a date confirmed by the papal bull preserved at the Fermo State Archive. However, German historian Heinrich Denifle (1844-1905) combined historiographical information and a lexicographic analysis of Latin used in papal bulls, and determined that it is more likely that the bull was issued in 1398. The papal document was probably forged in the fifteenth century, replacing the traditional lead seal with that of the papacy of Boniface VIII (1298 - 1303), bearing the inscription "Bonifatius PP.VIII." (Brizzi 2001).

\section{APPENDIX}

The individual human capital index $q_{i}$ of an individual $i$ is given by:

$$
\begin{aligned}
q_{i}= & -1.76+0.43 \ln (\mathrm{nb} . \text { of characters of the longest Wikipedia page }) \\
& +0.40 \ln (\mathrm{nb} . \text { of Wikipedia pages in different languages })+0.47 \ln (\mathrm{nb} . \text { of works in Worldcat }) \\
& +0.46 \ln (\mathrm{nb} . \text { of publication languages in Worldcat }) \\
& +0.47 \ln (\mathrm{nb} . \text { of library holdings in Worldcat })
\end{aligned}
$$

We assume that having no Wikipedia page is similar to having one page with a length of 60 characters and that having no Worldcat page is similar to having a page with one work in one language held by one library. The constant -1.76 normalizes $q_{i}$ at 0 when there is neither a Wikipedia page, nor a Worldcat page. The weights $(0.43,0.40$, etc) are obtained from the first principal component of the five indicators (De la Croix et al. 2020).

The notability $Q$ of a university aggregates the $q$ of the top 5 individuals who were active in the preceding 25 years using the following formula:

$$
Q=\sqrt{\sum_{i=1}^{5} \frac{1}{5}\left(\frac{q_{i}}{s_{i}}\right)^{2}}
$$

where $s_{i}$ is the number of universities at which $i$ had an appointment.

\section{ACKNOWLEDGMENTS}

This project has received funding from the European Research Council (ERC) under the European Union's Horizon 2020 research and innovation programme under grant agreement No 883033 "Did elite human capital trigger the rise of the West? Insights from a new database of European scholars." 
First version October 30, 2021.

\section{REFERENCES}

Britannica, The Editors of Encyclopaedia. January 2021. "Matteo Bandello.". Encyclopedia Britannica. Also available at https://www.britannica.com/biography/Matteo-Bandello.

Brizzi, Gian Paolo. 2001. L'antica Università di Fermo. Milano-Fermo, Silvana.

Curi, Vincenzo. 1880. L’Università degli Studi di Fermo: notizie storiche. Ancona, Ernesto Aurelj.

De la Croix, David, Frédéric Docquier, Alice Fabre, and Robert Stelter. 2020. "The Academic Market and the Rise of Universities in Medieval and Early Modern Europe (1000-1800)." CEPR Discussion Paper 14509.

De la Croix, David, and Soraya Karioun. 2021. "Scholars and Literati at the Gregorian University in Rome (1551-1773)." Repertorium Eruditorum totius Europae 3:19-26.

Grendler, Paul F. 2019. Jesuit Schools and Universities in Europe 1548-1773. Brill Research Perspectives in Jesuit Studies. Brill.

Istituto dell'Enciclopedia Italiana. 1929. Treccani. Enciclopedia Italiana di scienze, lettere ed arti. Roma: Istituto dell'Enciclopedia Italiana. Also available at https://www.treccani.it/.

Sommervogel, Carlos. 1890. Bibliothèque de la Compagnie de fésus. Brussels: Oscar Schepens.

Zurlini, Fabiola. 2012. Formazione ed esercizio della professione medica a Roma e nella Marca Fermana nei secoli XVII-XVIII. EUM-Edizioni Università di Macerata. 